\title{
DISCRIMINAÇÃO ÉTNICA EM MOÇAMBIQUE: ELO-BASE QUE EXIGE ELIMINAÇÃO PARA PAZ EFEÇTIVA
}

\author{
ETHNIC DISCRIMINATION IN MOZAMBIQUE: LINK THAT REQUIRES \\ ELIMINATION FOR EFFECTIVE PEACE
}

Pedro João LAVIEQUE

Universidade Técnica de Moçambique, Direcção de Pós-Graduação, Avenida Albert Luthuli nos 418/438, Maputo, Moçambique. E-mail: mciudm@gmail.com; ORCID: 0000-0003-4476-0004

\author{
ARTICLE INFO \\ Article history: \\ Received 2020-08-29 \\ Accepted 2020-09-04 \\ Available online 2020-09-04
}

Palavras-chave: Conflitualidade. Discriminação étnica. Igualdade. Paz.

Keywords: Conflict. Ethnic discrimination. Equality. Peace.

RESUMO. Moçambique vive uma discriminação étnica asfixiante e humilhante entre os seus cidadãos. As várias formas de discriminação têm uma génese histórica, vigoram desde as guerras de ocupação, foram estimuladas pelo colonialismo e constituem uma das causas da acumulação de ódios entre grupos populacionais das regiões sul e centro-norte. Na criação da FRELIMO, no período da Luta Armada e depois da proclamação da Independência Nacional a discriminação étnica foi usada para dividir moçambicanos em superiores e inferiores. O presente artigo tem como objectivo reflectir sobre a discriminação étnica na sociedade moçambicana, considerando que a sua prática viola o princípio de igualdade, desqualifica os cidadãos, enfraquece a esfera governativa e influencia negativamente no fracasso dos acordos de paz celebrados. A questão é a seguinte: "a discriminação étnica não estará sendo usada como bússula orientadora na política moçambicana, ainda que documentos oficiais e o discurso público condenem?» Na busca de respostas duas hipóteses se colocam: (i) As elites políticas dominantes em Moçambique estimulam a discriminação étnica para manutenção do poder; (ii) A discriminação étnica é uma perspectiva divisionista, alimentada com intenção de criar desordem social. Adoptamos uma pesquisa de abrangência qualitativa, que se apoia numa criteriosa selecção e triagem da bibliografia relevante ao tema, destacando-se as obras frequentemente evitadas nas abordagens oficiais. A discriminação étnica é notória na selecção dos Deputados à Assembleia da República pelos Partidos Políticos e na formação do Governo. Ultimamente o candidato à Presidente da República pela FRELIMO é seleccionado não pela competência, mas pela origem étnica.

ABSTRACT. Mozambique is experiencing an asphyxiating and humiliating ethnic discrimination among its citizens. The various forms of discrimination have a historical genesis, they have been in force since the occupation wars which were stimulated by colonialism and are one of the causes of the accumulation of hatred among population groups in the south and central-north regions. In the creation of FRELIMO, in the period of the Armed Struggle and after the proclamation of National Independence, ethnic discrimination was used to divide Mozambicans into superiors and inferiors. This article aims to reflect on ethnic discrimination in Mozambican society, considering that its practice violates the principle of equality, disqualifies citizens, weakens the government sphere and negatively influences the failure of the peace agreements concluded. The question is: "Is ethnic discrimination not being used as a guiding compass in Mozambican politics, even though official documents and public discourse condemn it?" In the search for answers, two hypotheses arise: (i) The dominant political elites in Mozambique encourage ethnic discrimination to maintain power; (ii) Ethnic discrimination is a divisive perspective, nurtured with the intention of creating social disorder. We have adopted a qualitative research, which is based on a careful selection and sorting of the relevant bibliography to the theme, highlighting the works frequently 
avoided in official approaches. Ethnic discrimination is evident in the selection of Members of the Republic Assembly by Political Parties and in the formation of the Government. Lately the candidate for President of the Republic by FRELIMO is selected not for his competence, but for his ethnic origin.

\section{Introdução}

Moçambique é um vasto território que se situa na África Austral e estende-se por uma superfície de 799.380 quilómetros quadrados e uma linha de costa no Oceano Índico de 2.770 km. Com uma população de 30.066.648 habitantes, que representa um diversificado mosaico cultural, Moçambique possui uma diversidade étnica ${ }^{1}$ bastante expressiva, agrupadas de forma irregular, através das principais línguas maternas, quais sejam, o Bitonga, Cichopi, Cimanika, Cindau, Ciniyungwe, Cisena, Ciwutewe, Echuwabo, Ekoti, Elomwe, Emakhuwa, Lolo, Shimakonde, Shona, Xichangana, Xironga e Xitshwa², bem como as suas ramificações.

O tema deste artigo é «Discriminação Étnica em Moçambique: Elo-base que exige eliminação para Paz efectiva» e o nosso objectivo é reflectir sobre a discriminação étnica na sociedade moçambicana, que se repercute no quotidiano dos cidadãos na esfera governativa e influência nos processos de busca da Paz, dada a sua omissão nas agendas negociais e nos acordos celebrados. Tendo em conta as desigualdades em curso no país, que constituem um perigo à paz, colocamos a seguinte questão: a discriminação étnica não estará sendo criteriosamente usada como bússula para orientar a navegação política em Moçambique, ainda que documentos oficiais orientadores e o discurso público condenem a discriminação de forma veemente? $\mathrm{Na}$ busca de respostas partimos com duas hipóteses: (i) As elites políticas dominantes em Moçambique estimulam a discriminação étnica na sua acção governativa como forma de manutenção do poder, receiam que a sua hegemonia decisória nos destinos do país lhes escape e caia nas mãos de castas inferiores não confiáveis; (ii) A discriminação étnica é um falso alarme, uma perspectiva alimentada por pessoas malintencionadas, com intenção divisionista e para criar desordem social.

O estudo deste tema reveste-se de grande relevância e actualidade, na medida em que é imperioso que a igualdade dos moçambicanos, consagrada constitucionalmente, seja preservada, porque a sua ausência aumenta o clima de conflitualidade, já que, de forma crescente é notável o fomento ao ódio e indignação no seio da sociedade que, consequentemente, resvala em guerras. Perante adversidades de vária natureza que assolam Moçambique, a «Unidade Nacional» devia ser o pilar incontornável de cidadania e ponto de convergência das famílias, longe da sinistra sombra do complexo de superioridade ou de inferioridade, estimulado pela discriminação étnica.

\footnotetext{
${ }^{1}$ Para ver a distribuição étnica pelo território, vide o mapa publicado no Atlas de Moçambique, editado pela Empresa Moderna de Lourenço Marques (actual Cidade de Maputo), no ano de 1960. <https://macua.blogs.com/moambique para todos/2012/09/grupos-\%C3\%A9tnicos-de-mo\%C3\%A7ambique.html>. Acesso em 15 de Maio de 2020.

2 Dados do Instituto Nacional de Estatística de Moçambique, disponíveis em: <http://www.ine.gov.mz/>. Acesso em 21/06/2020.
} 


\section{Metodologia}

O cenário de estudo gira em torno da igualdade constitucional e a justa partilha de oportunidades, tendo em conta que "Todos os cidadãos são iguais perante a lei, gozam dos mesmos direitos e estão sujeitos aos mesmos deveres, independentemente da cor, raça, sexo, origem étnica, lugar de nascimento, religião, grau de instrução, posição social, estado civil dos pais, profissão ou opção política." (artigo 35 da Constituição da República de Moçambique). Relacionado ao problema da pesquisa adoptamos o método indutivo numa pesquisa bibliográfica de abrangência qualitativa, que se apoia numa criteriosa selecção e triagem de obras, principalmente as que têm sido evitadas por diversas entidades oficiais na abordagem de várias matérias. Tanto é assim que em Moçambique persistem, ainda, correntes ideológicas que definem fidelidade para com o regime governamental, correntes essas que induzem à auto-censura para proteger, na paisagem científica, o posicionamento do poder dominante. Esse cenário leva a que, sem que se esteja a observar algum comando normativo específico, algumas obras sejam desclassificadas, olhando o autor e a sua origem, inventariando-se aproximações ou afastamentos junto das hordas do regime. Desse exercício resulta designar algumas obras por politicamente incorrectas, entendidas como réplicas reaccionárias, em contraposição das outras que se colam à linha governamental e gozam de recomendação oficial para todos os efeitos. A justificação da nossa opção à bibliografia ignorada ou veladamente silenciada traduz o entendimento de que no processo da compreensão das origens da conflitualidade ininterrupta em Moçambique, nos esforços da busca de paz efectiva, a análise deve mergulhar em todas as fontes possíveis, dando maior destaque ao conteúdo da bibliografia politicamente evitada.

\section{Fundamentação teórica}

A abordagem sobre discriminação é vasta e complexa. Na sua essência, a discriminação consiste numa acção ou omissão que dispense um tratamento diferenciado (inferiorizado) a uma pessoa ou grupo de pessoas, em razão da sua pertença a uma determinada raça, cor, sexo, nacionalidade, origem étnica, orientação sexual, identidade de género, religião, situação económica ou qualquer outro factor ou aspecto social. Discriminação significa, pois, uma distinção ou diferenciação e ocorre quando alguém adopta uma atitude preconceituosa (baseada em ideias preconcebidas), em relação a uma pessoa ou a um grupo de pessoas. ${ }^{3}$ A discriminação, em qualquer das suas manifestações, afasta a

3 Informação disponível nos seguintes sites: <https://apav.pt/uavmd/index.php/pt/intervencao/discriminacao> e <https://www.significados.com.br/discriminacao/>. Acessadas no dia 15 de Junho de 2020. 
harmonia e paz entre as pessoas. Uma atitude discriminatória resulta na violação do artigo 7 da Declaração Universal dos Direitos Humanos (1948), que estabelece imperativamente que "Todos são iguais perante a lei e têm direito, sem qualquer distinção, a igual protecção da lei. Todos têm direito a igual protecção contra qualquer discriminação que viole a presente Declaração e contra qualquer incitamento a tal discriminação". A Organização das Nações Unidas, entre outras funções, é responsável por promover diversas medidas voltadas à erradicação de todos os tipos de discriminação, pois ela resulta na segregação e exclusão social dos indivíduos discriminados, que se vêem menos representados e marginalizados na sociedade.

Em Moçambique a discriminação étnica possui raízes históricas profundas e bastante variadas. De entre os diversos aspectos que tipificam a sua manifestação e sustentam o seu aparecimento, debruçamo-nos à volta de dois, dada a brevidade deste artigo: a revolução sulafricana, conhecida como efeito Mfecane (a) e a política colonial portuguesa (b), desenhada com o claro propósito de dividir e desorientar os colonizados para melhor explorar e reinar.

\section{a) Efeito Mfecane}

Os anais da história registaram que os primeiros decénios do século XIX foram marcados por uma poderosa revolução social e política, que, simultaneamente teve por efeito a destruição e a reedificação da organização dos Estados da África Austral de língua banta, bem como a transformação das condições de existência de numerosas comunidades nos territórios que vão dos confins da Zululândia (Natal, África do Sul) até o sul da Tanzânia. Em Moçambique são visíveis os traços Nguni nas Províncias de Gaza, Tete e Nampula. Esta revolução denominada Mfecane (esmagamento) na língua Nguni, também é conhecida sob o nome de Difaqane (golpe de martelo) em Sotho-Tswana. Durante o Mfecane vários Estados antigos foram vencidos, conquistados e anexados a outros. Alguns Estados foram arrancados de seus territórios tradicionais e forçados a se implantar em território alheio, o que deu azo para que muitos se encontrassem, então, empobrecidos e enfraquecidos. Em certos casos, as antigas dinastias reinantes foram suplantadas ao passo que em outros lugares, as populações de aldeias inteiras eram aniquiladas ou capturadas. ${ }^{4}$

É dentro desta perspectiva que deve ser compreendido o Império de Gaza, fundado pelo povo nguni (vátuas ou aungunes, na terminologia colonial), um dos ramos dos zulus, provenientes da África do Sul e empurrados pela guerra civil, no efeito Mfecane. O reinado do

História Geral de África, do Século XIX a década de 1880, p. 106. Disponível em: $<$ https://books.google.co.mz/books?id=40x6CcmwLkAC\&pg=PA106\&lpg=PA106\&dq=Efeito+Mfecane\&source=bl\&ots=sxJRiMH C2d\&sig=ACfU3U2FJCPt0Mwvtxi NS1xMWFRda QWg\&hl=pt-

PT\&sa=X\&ved=2ahUKEwi589Das 7pAhUsQEEAHSAeAKUQ6AEwAnoECAoQAQ\#v=onepage\&q=Efeito\%20Mfecane\&f=false >. Acesso em 13 de Junho de 2020. 
Gungunhana, vigorou de 1884 a 28 de Dezembro de 1895, e o império estendeu-se do rio Incomáti à margem esquerda do Zambeze, e do Oceano Índico ao curso superior do rio Save. ${ }^{5}$

Em bom rigor, a invasão Nguni nunca devia ser motivo de orgulho dos moçambicanos ou base de discriminação étnica, pelo contrário devia causar repugnância e revolta, visto que essa invasão humilhou moçambicanos no seu próprio território, que o diga o povo Valengue que, pela superioridade das suas setas no campo de batalha, ganhou dos Ngunis o actual nome de Cichopi. Parece-nos defensável afirmar que se a invasão Nguni é motivo de orgulho e celebração, representa alguma identidade pátria, então que se celebre, de igual modo, a invasão portuguesa, já que ambos, apesar de momentos diferentes, invadiram o território, mataram pessoas nas suas aldeias, humilharam os nativos e apropriaram-se das suas riquezas.

\section{b) Colonização portuguesa}

O colonialismo português adoptou vários cenários para quebrar a unidade dos moçambicanos e, dessa forma, inviabilizar revoltas contra o seu regime. A política colonial estava direccionada à exploração dos recursos e matérias-primas que a indústria da metrópole precisava. Para melhor explorar estimulou, ao longo da colonização, a discriminação racial, étnica e religiosa, acompanhada de assimetrias de desenvolvimento regional (História de Moçambique, 2000).

A discriminação era difundida e aplicada a ferro e fogo e foi recebida com satisfação por etnias que pela história sentiam-se superiores por natureza. Sentindo-se reconhecidos pelo colonizador essas etnias foram ampliando o seu complexo de superioridade em relação a outras etnias, ensinando às novas gerações, na sagrada oralidade das típicas fogueiras da tarde. A região sul de Moçambique, onde o colonialismo português tinha maior concentração e, simultaneamente, o maior volume de investimentos, sentiu-se mais privilegiada e com superioridade expressiva, em relação às restantes regiões do território.

O estímulo à discriminação racial, étnica e religiosa gozava de fundamento legal, através da Lei no 2.066, de 27 de Julho de 1953, Lei Orgânica do Ultramar. Porém, de forma específica, cabia à interpretação das disposições do Estatuto dos Indígenas Portugueses das Províncias da Guiné [Bissau], Angola e Moçambique, aprovado pelo Decreto-Lei no 39.666, de 20 de Maio de 1954. Diferentemente de outras potências colonizadoras, os portugueses estabeleceram uma verdadeira colonização jurídica. "O Direito é uma das áreas em que o pensamento burguês se exprimiu com muita elaboração, subtileza e técnica. O seu

\footnotetext{
${ }^{5}$ Fonte: <https://www.gaza.gov.mz/por/A-Provincia/Historia-de-Gaza>. Acesso em 12 de Junho de 2020.
} 
refinamento chegou ao extremo de se conseguir apresentar como neutro, como superior às classes, como intemporal e como universal." ${ }^{\circ} \mathrm{O}$ Direito legitimava desigualdades e opressão.

\section{Consequências da discriminação étnica em Moçambique}

São várias e devidamente conhecidas as consequências derivadas da discriminação étnica em Moçambique. De entre elas seleccionamos as que nos pareceram significativas para este trabalho, conforme o desenvolvimento que segue:

\subsection{Discriminação étnica na fundação da FRELIMO e ao longo da guerra}

Ao longo da colonização portuguesa o sistema discriminatório floresceu na sociedade moçambicana e marcou uma assinalável presença na fusão dos três movimentos nacionalistas que, de forma separada, se opunham ao domínio português: (i) União Democrática Nacional de Moçambique (UDENAMO); (ii) A Mozambique African National Union (MANU); (iii) A União Africana de Moçambique Independente (UNAMI). ${ }^{7}$ A fusão resultou na criação da Frente de Libertação de Moçambique (FRELIMO) e para dirigir a frente foi dada liberdade para cada movimento nacionalista apresentar candidaturas, de entre os seus integrantes. Dos três movimentos nacionalistas a UDENAMO merece a nossa análise em matéria de discriminação, visto que ela tinha nas suas fileiras moçambicanos naturais das regiões sul e centro, e como este movimento se comportou durante o processo de candidatura e eleições.

Para concorrer à presidência da FRELIMO a UDENAMO tinha o seu líder histórico, Adelino Gwambe, (da região sul), porém, a sua idade e nível de escolaridade eram inferiores e não dignificavam a representação do movimento. Uria Simango (da região centro), tinha idade e formação adequadas para representar o movimento candidatando-se à liderança da FRELIMO. Certos autores sustentam que sendo natural da região centro o grupo da região sul não se sentiu confortável, opôs-se instintivamente à possível liderança de Uria Simango. Com base numa hipotética superioridade ou inferioridade étnica, nasceu na circunstância, logo à partida, a luta pelo poder, entre o sul e centro-norte.

Do imaginário estabeleceu-se a fronteira geográfica através do rio Save, conduzindo actos para evitar que o poder de direcção fosse exercido a norte daquele rio. Tratava-se da afirmação de um grupo sobre o outro, revelava-se a manifestação da discriminação étnica que agora afastava a igualdade e liberdade, caminhando perigosamente em direcção à luta pelo poder. FANUEL MAHLUZA (natural do sul do rio Save), membro fundador da UDENAMO,

\footnotetext{
${ }^{6}$ Extracto do relatório do Comité Central do Partido FRELIMO ao IV Congresso, na parte relativa à Justiça.

${ }^{7}$ Para mais informações, vide, VIEIRA, Sérgio. Participei, por isso testemunho, pp. 194-198; Memórias da Revolução $1962-1974$ (Colectânea de entrevistas de Combatentes da Luta de Libertação Nacional), Volume I, Maputo, 2011.
} 
socorre-se da história para afirmar que "é um conflito que houve séculos atrás entre os filhos de Soshangane, Ndawe e Tsonga e que deram origem a rivalidade entre os ndaus e tsongas, sendo ambos os grupos descendentes dos filhos de Soshangane."8 O Tsonga (xiTsonga, chiTsonga) ou shiTsonga (em inglês) é um idioma da África Austral, falado em Moçambique, África do Sul e Zimbabwe. Em Moçambique constitui o tronco linguístico comum das três línguas faladas a sul do rio Save, quais sejam, o Xironga, o Xichangana e Xitshwa (ARMINDO NGUNGA, et al, 2012).

Sobre Ndaus e Tsongas - escrevem vários autores - o que estava em causa não era a capacidade ou integridade pessoal, muito menos o nacionalismo dos indivíduos, era a discriminação com base na origem étnica, pelo que mostrava-se importante tomar providências desde cedo, para não entregar o poder a etnias inferiores. Assim, resulta claro que a criação da FRELIMO ocorreu de forma discriminatória, ainda que nos articulados dos respectivos Estatutos conste a importância da unidade dos nacionalistas e condene todos os tipos de discriminação. (BARNABÉ NCOMO, 2003; ADELINO TIMÓTEO, 2019)

FANUEL MAHLUZA explica que foi ele e Calvino Mahlayeye que formularam o convite a Eduardo Mondlane, então nos Estados Unidos da América (EUA) para deslocar-se a Tanganyika, de modo a participar na fusão dos movimentos nacionalistas e consequente criação da FRELIMO, marcada para dia 23 de Junho de 1962. Os dois escreveram a carta como Tsongas para outro Tsonga, especificando que "escrevemos em tsonga para ele compreender melhor o nosso pensamento, porque queríamos que ele entendesse a essência cultural do problema (...) tínhamos como razões tribais e de complexo de inferioridade intelectual, porque apesar de sermos a maioria, eramos semi-intelectuais." 9

FANUEL MAHLUZA e ANTÓNIO ZENGAZENGA ${ }^{10}$ escrevem que Eduardo Mondlane aceitou o convite, deslocou-se ao Tanganyika, recebeu o Cartão de Membro da UDENAMO com quem concorreu à presidência da FRELIMO e foi eleito Presidente. Por seu turno, Uria Simango também concorreu pela UDENAMO à presidência da FRELIMO e ficou em segundo lugar, tornando-se Vice-Presidente. O posicionamento de Uria Simango em segundo lugar confirma a sua aceitação no seio dos nacionalistas para dirigir a FRELIMO, não fosse o carisma de Mondlane ele venceria o pleito, o que justifica os receios iniciais dos seus oponentes.

\footnotetext{
8 Para mais informações, vide, em: <https://macua.blogs.com/moambique para todos/2011/01/fanuel-malhuza-continua-adesafiar-as-teses-da-frelimo-sobre-a-hist\%C3\%B3ria.html>. Acesso em 10 de Junho de 2020. Entrevista dada a Salomão Mayana, SAVANA de 27 de Outubro de 2000.

9 Fonte: GUAMBE, Eusébio A. P. Disponível <https://ambicanos.blogspot.com/2016/12/foi-fanuel-gideon-mahluza-quemconvidou.html >. Acesso em 10 de Junho de 2020.

${ }^{10}$ Dr. António Disse Zengazenga nasceu na aldeia de Salamadze, no distrito de Angónia, província de Tete, em 6 de Outubro de 1933. Foram António Disse Zengazenga, Uria Timóteo Simango e Refael Silvério Nungu, que estrangularam a revolta contra Eduardo Chivambo Mondlane organizada por José David Mabunda, José Paulo Gumane e Fanuel Guidion Mahluza a 3 de Outubro de 1962 em Dar-es-Salaam.
} 
Os integrantes da UDENAMO, com destaque para Fanuel Mahluza e António Zengazenga, sustentam de forma categórica, que o tribalismo/etnicismo, a luta pelo poder entre moçambicanos do sul e centro-norte, constituíram a base originária da FRELIMO, ou seja, o etnicismo serviu de holofote que guiou a organização desde o início, cobrindo de forma subtil, toda a política da FRELIMO ao longo da sua existência.

Escreve BARNABÉ NCOMO (2003) que durante a Luta Armada de Libertação Nacional foram denunciadas manifestações de etnicismo, sendo a mais grave a realização de reuniões periódicas e clandestinas dos militantes originários da região a sul, ora designados simplesmente como «Grupo do Sul». Esses encontros que ocorriam à margem dos fóruns estabelecidos nos Estatutos da FRELIMO decidiam sobre estratégia a adoptar no seio da organização para manter bem alta a hegemonia étnica, de modo a assegurar a manutenção do poder. Embora conscientes da sua atitude negativa que quebrava a unidade da guerrilha, os autores agiam indiferentes quanto às implicações ou consequências para o futuro da FRELIMO (LAWE LAWEKI, 2019; BARNABÉ NCOMO, 2003).

O grupo do Sul (minoritário) teve uma aliança estratégica com uma etnia do norte, também minoritária, Shimakonde, para abafar a voz e actividades de um makonde carismático e influente, Lázaro Nkavandame, Secretário Provincial de Cabo Delgado e líder do Conselho dos Anciãos (Baraza-la-Wazee) que tinha fortes relações com o Conselho dos Anciãos em Dar-es-Salaam, liderado por Mzee Mchekecha. Nkavandame assustava o grupo do Sul. (BARNABÉ NCOMO, 2003; LAWE LAWEKI, 2019).

Depoimentos de antigos combatentes, constantes em diversas obras publicadas em Moçambique, sugerem que o primeiro alvo visado nos encontros do Grupo do Sul foi Filipe Samuel Magaia (1937-1966), natural de Mocuba, província da Zambézia, filho de Gunguene Magaia (da etnia Xironga), um enfermeiro de profissão, e de Ana Albino Pereira (de etnia Echuwabo, do centro). Filipe Magaia foi o primeiro comandante da guerrilha da FRELIMO, que assumia simultaneamente os postos de Chefe do Departamento de Defesa e Segurança e membro do Comité Central. Na entrevista concedida por Fernando Mungaka a BARNABÉ NCOMO (2003, pp.147-154) consta que Filipe Magaia para além de Mocuba onde nasceu e Lourenço Marques onde estudou, viveu na Cidade da Beira, vivências que Ihe conferiam a habilidade de demonstrar uma verdadeira unidade nacional, na sua maneira de ser e de estar, pelo que mesmo sendo filho de pai Xironga ele era olhado como da região centro-norte e o «Grupo do Sul» encarava-o com reservas (BARNABÉ NCOMO, 2003; ADELINO TIMÓTEO, 2017; ADELINO TIMÓTEO, 2019; LAWE LAWEKI, 2019).

Eduardo Mondlane é tido como tendo começado com um ensaio de destituição de Filipe Magaia das suas funções, intenção frustrada porque não havia motivo bastante para convencer o Comité Central para o efeito. Na deslocação que Filipe Magaia fez à província de Niassa, dirigindo um grupo de guerrilheiros foi assassinado a queima roupa por Lourenço Matola (da etnia Xironga), um guerrilheiro que integrava a sua comitiva. Consumado o crime 
e mesmo conhecendo-se o assassino a FRELIMO não formalizou a respectiva queixa junto das autoridades tanzanianas, pelo que o crime não teve o tratamento adequado (BARNABÉ NCOMO, 2003).

Eduardo Mondlane, o Presidente da FRELIMO, ignorou Casal Ribeiro (do centro) e Adjunto do defunto Comandante, subdividiu as funções que Filipe Magaia exercia em duas partes: para Chefe do Departamento de Defesa (Comandante da guerrilha da FRELIMO) nomeou Samora Machel e para Chefe do Departamento de Segurança (Serviços de inteligência da FRELIMO) nomeou Joaquim Chissano (ambos da etnia Xichangana). A morte de Filipe Magaia foi interpretada pelos guerrilheiros oriundos do centro-norte como operação orquestrada e bem-sucedida para a afirmação do Grupo do Sul, na medida em que as duas funções representavam poder, quer durante a guerra, como depois de alcançar a Independência Nacional (LAWE LAWEKI, 2019).

Outros autores escrevem ainda que em vida Filipe Magaia namorava a Josina Muthemba e, após a sua morte, ela casou-se com Samora Machel, em Maio de 1969, associando-se de forma suspeita o facto da pessoa que o substituiu no posto de comandante da guerrilha, ser a mesma que também o substituiu no seu relacionamento afectivo. $\mathrm{Na}$ entrevista que Janet Mondlane ${ }^{11}$ concedeu à jornalista Rosa Langa, no livro «Moçambique, mulheres e vida», ao revelar o romance entre Samora Machel e Josina Muthemba, ela terá dito que "aquele assunto deu muita polémica porque antes a Josina tinha sido namorada de Filipe Samuel Magaia, assassinado, e Samora tinha sido acusado de ter ficado com a posição de Filipe como Comandante e de tirar também a mulher do outro."12 Essas fontes estabelecem essa conexão pelo facto de em África, a humilhação ao adversário vencido, consiste em apoderar-se da sua própria mulher, simbolizando com isso uma completa dominação, pior quando o vencido é considerado de casta inferior, como parece ser a indução das fontes no enquadramento deste caso.

Zeca Caliate um comandante dissidente da guerrilha na província de Tete, natural de Milange (Zambézia) e muito próximo do defunto Comandante, afirma em artigo de 13 de Abril de 2017, que depois da morte de Filipe Magaia verificou-se uma verdadeira caça às bruxas, em que foram seleccionados e assassinados todos os comandantes e demais guerrilheiros que Ihe eram fiéis. Caliate apresenta uma lista de 55 guerrilheiros assassinados, na sua maioria originários das regiões centro e norte. ${ }^{13}$ Aliás, o maior número dos chamados reaccionários, muito publicitados nos manuais da FRELIMO, que foram fuzilados ou

\footnotetext{
${ }^{11}$ Esposa de Eduardo Mondlane, primeiro Presidente da FRELIMO.

12 NHACHOTE, Luís, referindo-se à entrevista que fizera a Janet Mondlane, no dia 3 de Fevereiro de 2006 , sobre as circunstâncias da morte do marido. Para mais informações sobre este assunto, vide, CANALMOZ de 23 de Outubro de 2009 ; vide, ainda, em: <https://macua.blogs.com/moambique para todos/2009/10/janet-mondlane-deve-falar-com-a-filha.html>. Acesso em 4 de Janeiro de 2020.

13 Fonte: <https://macua.blogs.com/moambique para todos/2017/04/zeca-caliate-a-voz-da-verdade-listagem-nominalprovis\%C3\%B3ria-de-compatriotas-assassinados-a-sangue-frio.html>. Acesso em 10 de Junho de 2020. Vide, ainda, em: <https://ameliaautincan.blogspot.com/2019/11/lista-de-assassinados-no-seio-da-frelimo.html>. Acesso em 10/Junho/2020.
} 
desapareceram misteriosamente, era de naturalidade centro-norte. SALÉSIO NALYAMBIPANO (2013, p. 252) lamenta e assume sentir remorsos por não ter fuzilado Miguel Murrupa (da etnia Elomwe) ${ }^{14}$, tal como fizera com outros "traidores" que passaram das suas mãos. Nalyambipano e Lagos Lidimo são os operativos da etnia Shimakonde a quem são atribuídos vários assassinatos, no contexto da aliança com o Grupo do Sul.

O padre Mateus Gwenjere, é descrito como figura do centro-norte de Moçambique que se notabilizou na mobilização, recrutamento e envio à Tanzânia de jovens para integrar na Luta Armada. O padre chegou a Tanzânia no dia 12 de Setembro de 1967, onde foi recebido efusivamente não só por Eduardo Mondlane, mas por vários dirigentes da frente e pelos membros do governo tanzaniano. Confirma-se que no dia 7 de Novembro de 1967 discursou nas Nações Unidas, para depor contra Portugal. Certos autores escrevem que ao tomar conhecimento da existência do Grupo do Sul o padre não se conformou, tendo-se tornado figura incómoda, dada a sua verticalidade. Para ser afastado o seu nome foi associado à crise do Instituto Moçambicano - que já existia quando ele chegou a Tanzânia - acabando por ser expulso da FRELIMO e do território tanzaniano. Exilou-se no Quénia e vivia em Riruta, arredores de Nairobi, onde a 10 de Outubro de 1975 seria raptado e posteriormente assassinado. ${ }^{15}$

Eduardo Mondlane perdeu a vida no dia 3 de Fevereiro de 1969. A teoria mais difundida pela FRELIMO é de que foi a Polícia Internacional e de Defesa do Estado - Direcção Geral de Segurança (PIDE-DGS), a polícia política portuguesa ${ }^{16}$ quem o matou, através de uma carta armadilhada enviada da Alemanha. Essa tese foi reforçada pelas afirmações do português Rosa Casaco ao «Expresso», em 1998, que incriminava a antiga PIDE-DGS. A FRELIMO elaborou várias vezes a ideia de que Uria Simango, Vice-Presidente teria ajudado na conjura. Lutero Simango, o filho mais velho de Uria Simango, numa entrevista que concedeu a TÂNIA ALVES (2017, p. 117) negou que Mondlane tenha sido morto por uma ala dirigida pelo pai, sustentando que se tivesse sido assim, essa ala teria assumido a liderança pela força, já que "em qualquer parte do mundo, quando há um golpe de Estado, os golpistas assumem a liderança”. Na análise que fez à obra «Uria Simango, um homem, uma causa» de Barnabé Ncomo, MICHEL CAHEN (2010, p. 208) escreve que "durante estas lutas iniciais, Uria Simango esteve infalivelmente do lado de Eduardo Mondlane. E pode pensar-se que não foi apenas por concessão, vontade de unidade, etc., mas porque Uria Simango e Eduardo Mondlane tinham, eles também, trajectórias «modernas» e um imaginário nacional e social compatíveis."

\footnotetext{
${ }^{14}$ Miguel Murrupa desentendeu-se com a ala revolucionária da FRELIMO, foi enviado pela Direcção da FRELIMO à Base Central Moçambique, para o Salésio Nalyambipano o mandar ao Campo de Reeducação em Cabo Delgado. Miguel Murrupa escapou com vida entregou-se às fileiras portuguesas.

${ }^{15}$ Notas de Lawe Laweki: CABRITA, João M., correspondence with author at un-kept date.

${ }^{16}$ A PIDE-DGS foi criada pelo Decreto-Lei no 35.046, de 22 de Outubro de 1945, vigorou de 1945 a 1969 e tinha como atribuições: Polícia Judiciária nos sectores de estrangeiros, fronteiras e Segurança do Estado.
} 
De acordo com os Estatutos da FRELIMO, em caso de impedimento permanente do Presidente cabia ao Vice-Presidente substituir-Ihe. Assim, com a morte de Eduardo Mondlane seria Uria Simango quem devia assumir a presidência, mas foi impedido pelo Comité Central da FRELIMO, e designado um conselho da presidência constituído por Samora Machel, Marcelino dos Santos e o próprio Uria Simango. Ainda em 1969 Uria Simango denunciou irregularidades na FRELIMO num documento intitulado «Glomy Situation in Frelimo» (Triste Situação da Frelimo), com destaque para manifestações de tribalismo dos sulistas e a marginalização dos grupos de centro e norte, nos seguintes termos:

Desde 1966, tem-se manifestado uma tendência no grupo, infelizmente composto por gentes do sul, que incluíam o falecido presidente da Frelimo, no sentido de tomarem decisões por eles próprios e impô-las aos outros por meio das suas manobras. O falecido presidente foi criticado por certas pessoas do Sul pelas consequências que este método poderia trazer na causa final. Não se fez caso deste aviso. Este grupo continua com este método. Realizaram-se vários encontros na casa de Janet [esposa de Eduardo Mondlane] tendo tomado parte neles só os membros da tribo. (apud CHICHAVA,2008, p. 5). ${ }^{17}$

Posteriormente, Uria Simango viria a ser expulso da FRELIMO, em Maio de 1970, alegadamente devido às suas tendências "reaccionárias" (BARNABÉ NCOMO, 2003). A morte de Mondlane aconteceu num momento de desconfianças e lutas intestinas dentro da FRELIMO. Um mês antes fora afastado Lázaro Nkanvadame, também "um reaccionário", do posto de secretário para a província de Cabo Delgado. Joaquim Chissano é descrito como tendo em sua posse um relatório com pormenores do assassínio de Eduardo Mondlane que inclui um inquérito que Julius Nyerere mandou fazer, com a colaboração da Scotland Yard e Interpol, documentos que nunca foram divulgados. ${ }^{18}$

Vários autores insinuam que a União Soviética e a China não se sentiam confortáveis com a presidência de Eduardo Mondlane, pelo facto de ele ter estudado nos EUA, casado com uma mulher americana e comungar da cultura ocidental, pelo que a sua morte serviria para colocar no topo da guerrilha alguém que alinharia, de forma clara, com o bloco socialista (Moscovo, Pequim, Havana, etc.), capitais de países que forneciam armamento, ministravam diversos cursos de inteligência e treinamento militar. JOSÉ DUARTE DE JESUS, Embaixador e Professor do Instituto Superior de Ciências Sociais e Políticas (ISCSP) sustenta que

\footnotetext{
17 Para mais informações, vide: MABONGO, António Wiliamo (2015). Diversidade étnica e exclusão social no processo da consolidação da unidade nacional: $\mathrm{O}$ caso dos vendedores e vendedoras informais do mercado de Estrela Vermelha - cidade de Maputo, Dissertação ao Curso de Mestrado em Relações Interculturais na Universidade Aberta. Fonte: $<$ https://repositorioaberto.uab.pt/bitstream/10400.2/5293/1/TMRI Antonio Mabongo.pdf>. Acesso em 12 de Junho de 2020.

${ }_{18}$ Mais informações, vide entrevista de Sérgio Vieira a DW, disponível em: <https://www.dw.com/pt-002/eu-n\%C3\%A3o-tenhoa-minha-vers\%C3\%A3o-da-morte-de-mondlane-mas-a-vers\%C3\%A3o-diz-s\%C3\%A9rgio-vieira/a-17550713>. Acesso em 4 de Janeiro de 2020. Para mais informações, vide, SAMPAIO, Zito (2012:47-48). Um homem, mil exemplos - a vida e a luta de Mariano de Araújo Matsinha, Plural Editores, Maputo; NALYAMBIPANO, Salésio Teodoro (2013:106). A minha contribuição para a Independência e edificação do Estado Moçambicano, Memórias de um General da Linha de Frente, Gabinete da Presidência da República, Maputo.
} 
Mondlane era o fiel da balança entre os dois blocos na Guerra-Fria e quem saiu a ganhar com a sua morte foi a União Soviética e os elementos radicais da FRELIMO. ${ }^{19}$

VLADIMIR SHUBIN, escreveu no seu livro, "The Hot "Cold War"- The USSR in Southern Africa», uma série de inquietações da União Soviética em relação a Eduardo Mondlane, descrevendo que pouco tempo depois da formação da FRELIMO, a União Soviética manifestou-se apreensiva pelo facto da direcção do movimento de libertação moçambicano ter ficado nas mãos de Eduardo Mondlane. ${ }^{20}$ Latyp Maksudov, representante soviético na Organização de Solidariedade Popular Afro-Asiática, abordara o nacionalista angolano, Mário Pinto de Andrade, a quem pedira a sua opinião a respeito de Eduardo Mondlane, pedido semelhante feito posteriormente a Marcelino dos Santos da FRELIMO. Pinto de Andrade é descrito como tendo afirmado que "Mondlane não dificulta o trabalho de Marcelino dos Santos, e aqui muito pode ser feito. O Marcelino dos Santos está a trabalhar, e portanto a FRELIMO existe e actua". Por seu turno, Marcelino dos Santos terá afirmado que Mondlane era único homem, negro, educado com ligações financeiras no estrangeiro, capaz de angariar fundos. ${ }^{21}$ Disse que "decidimos logo de princípio deixar que Mondlane permanecesse na direcção do movimento, e nós iremos trabalhar no seio do movimento e guiar a frente (...) mais tarde, se for necessário, será possível substituir Mondlane". ${ }^{22}$

Alguns autores asseguram que apesar destas evidências que sugerem de onde, possivelmente, podia vir, também, a ordem de assassinato, e das circunstâncias vividas, as fontes alinhadas com a elite dominante atribuem a morte de Eduardo Mondlane a Uria Simango, na complexa perspectiva de induzir a que tudo o que fosse negativo, todos os problemas e erros no seio do movimento sejam imputados a pessoas de origem centro-norte, mantendo firme a heroicidade e integridade das castas superiores do sul, confirmando o que escreve CARLOS SERRA (2000, p. 39), citando José Macaringue, segundo o qual "Esses gajos do Sul são muito invejosos e fazem de tudo o que estiver ao seu alcance para prejudicar as pessoas do Norte, a quem tratam por xingondos."

A Luta Armada que teve início no dia 25 de Setembro de 1964 terminou com a assinatura dos Acordos de Lusaka, a 7 de Setembro de $1974^{23}$ que proclamaram o cessarfogo e marcaram o dia 25 de Junho de 1975 como o dia da Independência de Moçambique. Além das consequências directas da luta, o texto final dos Acordos de Lusaka foi influenciado pelo Golpe de Estado havido em Portugal, no dia 25 de Abril de 1974, na chamada Revolução dos Cravos, que alterou o formato dos integrantes portugueses às Conversações de Lusaka (JORGE JARDIM, 1976; DAVID MARTELO, 2001; TÂNIA REIS ALVES, 2017).

\footnotetext{
19 Fonte: <https://www.publico.pt/2009/05/10/jornal/urss-foi-quem-mais-beneficou-com-assassinio-de-eduardo-mondlane-dizinvestigador-305862>. Acesso em 8 de Fevereiro de 2020.

${ }^{20}$ CANALMOZ de 27 de Outubro de 2009. Fonte: <https://ambicanos.blogspot.com/2012/07/marcelino-dos-santos-considerouafastar.html>. Para mais informações, vide, <http://debatesedevaneios.blogspot.com/2009/10/marcelino-dos-santos-considerouafastar.html >. Ambas consultadas em 10 de Março de 2020.

${ }^{21}$ Idem.

22 Ibidem.

${ }^{23}$ Boletim Oficial no 117, I Série, de 10 de Outubro de 1974.
} 


\subsection{Independência Nacional e ampliação das práticas discriminatórias}

A proclamação da Independência trouxe, publicamente, a vitória geral conquistada pela FRELIMO e, em particular ao Grupo do Sul na luta pelo poder vivida ao longo da Luta Armada, cujos reflexos podem ser comprovados pela composição do Primeiro Conselho de Ministros (Governo de Moçambique). Não tardou que na euforia dos comícios, reuniões dos Grupos Dinamizadores e diversos encontros políticos, os cidadãos naturais da região a Sul do rio Save fossem nomeados e colocados em lugares de chefia e de prestígio nas regiões centro-norte de Moçambique, sem obedecer as regras do Direito Administrativo, que estabelecem, imperativamente, que na Função Pública a lei é a base, o fundamento e fim de toda a actividade administrativa. Alguns autores sustentam que as novas autoridades violavam abertamente e de forma continuada o Estatuto do Funcionalismo Ultramarino, aprovado pelo Decreto-Lei oㅜ 46.982, de 27 de Abril de 1966 que, em princípio, estava ou devia estar em vigor. As movimentações na Administração Pública eram acompanhadas de outras medidas complementares, como a difusão da dança Makwayela, do sul, nas regiões centro-norte, o que é comparado como o colono impunha o Fado nas colónias em África.

Em 1978 a FRELIMO organizou uma reunião na Cidade de Nacala-Porto, destinada a discutir o «escangalhamento do Aparelho do Estado Colonial», na perspectiva de implantar um Estado Novo, com as características do Marxismo-Leninismo. Num Estado de Direito o órgão reunido em Nacala-Porto não teria nenhuma competência legislativa para revogar o Estatuto do Funcionalismo Ultramarino, porém o sistema socialista adoptado em 1977 fazia do Partido FRELIMO a entidade que simultaneamente dirigia os poderes Executivo, Legislativo e Judicial, o que era aproveitado para legitimar actos administrativos ilegais, praticados por pessoas incompetentes, agindo de forma abusiva e desproporcional nos processos de admissão, transferência, demissão e expulsão dos funcionários públicos. Não havendo a mínima observância às normas legais floresceu o nepotismo e acentuada discriminação étnica, em que os moçambicanos da região sul transformavam-se em novos colonos das regiões centro-norte de Moçambique, implantando no país a desigualdade.

Com a fuga de quadros muitos autores afirmam que os cidadãos nomeados não possuíam formação razoável e nem experiência profissional na Administração Pública. Foram promovidas pessoas estranhas à Função Pública, como serralheiros, mecânicos, soldadores e outros. 3 exemplos, de entre dezenas ou centenas de indivíduos nomeados e ou promovidos ao arrepio das normas administrativas: (i) o serralheiro-soldador Francisco Gauene Munguambe (da etnia Cichopi), que foi designado Administrador do Distrito de Malema, com simples Quarta Classe; (ii) Alberto Vasco Matavele (da etnia Xichangana), nomeado Chefe dos Serviços Provinciais da Agricultura de Nampula, com apenas Sexta Classe, para dirigir 
Engenheiros-Agrónomos e outros técnicos superiores; (iii) Vicente Lourenço Matavel (da etnia Xichangana), nomeado num processo bastante duvidoso em 1989, para Director Geral da Empresa do Algodão de Nampula. Autores consideram que o pior foi nomear e movimentar esses operários do sul ao centro-norte, ignorando os locais.

Os naturais do sul do rio Save consideram normal a prática do nepotismo nas nomeações, ainda que seja gente profissionalmente incapaz, sem visão para catapultar o desenvolvimento, mas porque pretende-se projectar a superioridade étnica na governação, pois os restantes moçambicanos são inferiores não confiáveis e sem vocação para dirigir. Entende-se que essa linha de raciocínio equipara-se com a dos portugueses, na sua relação com os indígenas, no auge da colonização. CARLOS SERRA, (2000, p. 42), citando Teles Huo escreve que "nem entre eles se entendem e se não fôssemos nós do Sul que estamos a governar este país seria como o Ruanda e outros países de África com sérios problemas e guerras tribais, nós os do Sul é que procuramos assegurar a unidade nacional, enquanto que esses gajos do Norte são todos uns tribalistas e gananciosos". Os zambezianos, por exemplo, consideram-se excluídos e marginalizados pelo regime excessivamente sulista, interpretam as nomeações como novas manifestações de colonização, como bem explica o arcebispo de Quelimane, Dom Filipe Governo:

No princípio, a Frelimo enviou quadros do sul, então os zambezianos interpretaram isso como um colonialismo do sul. Isso fez recuar a Zambézia em relação à Frelimo. Mesmo os administradores eram do sul, o chefe de apoio e controlo, mesmo o chefe do posto, eram do sul. Mesmo na Universidade [Eduardo Mondlane, principal universidade pública no Sul] quando o professor sabe que este estudante vem do Centro ou do Norte [do país], a probabilidade de ele [o estudante] chumbar é maior que a de um estudante do sul..."24

SÉRGIO CHICHAVA (2008), do Instituto de Estudos Económicos e Sociais (IESE), fez um estudo que foi notícia publicada pelo Magazine Independente ${ }^{25}$ em que Brazão Mazula e Carlos Machili, dois quadros seniores da FRELIMO e naturais de Niassa, acusavam Arnaldo Bimbe, natural de Gaza ${ }^{26}$ e Governador da Província de Niassa, de tribalizar a província na sua governação, por privilegiar determinadas tribos na distribuição de posições de prestígio político, económico e social em prejuízo de outras, fomentando, desse modo, tribalismo em Niassa. O estudo recua no tempo para lembrar que a discriminação étnica foi a base de motivação para criar um movimento separatista em relação à FRELIMO, a União Nacional da Rombézia (UNAR)27, em 1968.

Outro facto interessante abordado pelo IESE foi a emergência de associações étnicoregionais, que tinham no seu seio antigos ou futuros dirigentes da FRELIMO, entre as quais

\footnotetext{
${ }^{24}$ Entrevista de Chichava com o Arcebispo de Quelimane, Dom Filipe Governo, Quelimane, 09/10/2004.

${ }^{25} \mathrm{~N}^{\circ} 49$, do dia 12 de Março de 2008.

${ }^{26}$ Província do Sul de Moçambique, terra natal dos 3 Presidentes da FRELIMO.

${ }^{27}$ Existem dados documentados que sustentam que Kamuzu Banda, Presidente do Malawi, estaria por detrás da criação da UNAR, porque ele queria juntar esta larga extensão de Moçambique, que vai do rio Zambeze ao rio Rovuma (daí a designação ROMBEZIA), para formar o Grande Malawi.
} 
a SOTEMAZA (Sofala, Tete, Manica e Zambézia)28; Movimento Cívico de Solidariedade e Apoio à Zambézia (MOCIZA); Associação para o Desenvolvimento de Nampula (ASSANA); e a Associação dos Nativos e Amigos de Maputo (Ngiyana ou Nygana). ${ }^{29} \mathrm{Na}$ Ngiyana, pontificavam nomes de Armando Guebuza (ex-Presidente da República), Teodato Hunguana, Américo Mfumo, Raúl Honwana, entre outros. Na SOTEMAZA, constava, de entre outros, Pedro Comissário (da etnia Cisena), originário de Sofala e alto quadro da Frelimo. $\mathrm{Na}$ MOCIZA, constavam nomes sonantes de Hélder Muteia, Abdul Carimo, Pedro Murima, todos zambezianos. A SOTEMAZA e MOCIZA representavam as elites do vale do Zambeze, que durante muito tempo sentiram-se excluídas do poder pela FRELIMO. Na ASSANA, havia figuras como Adelaide Amurane, Dionísio Cherewa e Rosário Mualeia. Como escreve Sérgio Chichava, o aparecimento destas associações veio a acordar os particularismos.

Os autores sistematicamente ignorados pela linha oficial sublinham que os praticantes usuais do tribalismo, etnicismo e regionalismo, são exímios em inverter o cenário, adiantandose em acusar frequentemente as suas vítimas dessa prática. Este tipo de discriminação pontificam os autores - é bem conhecido na sociedade, de norte a sul, de tal sorte que todos os moçambicanos nascidos a norte do rio Save são chamados de «Xingondos», um nome pejorativo, interpretado como gente primitiva, atrasada e menos civilizada. Do "Sul" e especialmente de Maputo para "Centro/Norte" a estereotipagem não é menos intensa. Regra geral os naturais do "Sul" apresentam os do Norte como «atrasados», "conflituosos», «traidores», «brutos», «gajos violentos» e «tribalistas» (CARLOS SERRA, 2000, p. 41). Afirma-se que os naturais do Sul levaram a civilização ${ }^{30}$ aos naturais do Norte. Alguns autores afirmam que se por civilização entende-se a influência do estilo de vida europeia na ordem social dos nativos, então há aqui uma inversão na interpretação de quem levou essa civilização para quem, porque quando Lourenço Marques foi elevado a Vila, em 1875, mais tarde a Cidade, em 10 de Novembro de 1887, a capital estava no Norte, na llha de Moçambique, onde os europeus exerciam maior influência na vida das populações, ou seja, difundiam a sua forma de viver. A transferência da capital para Lourenço Marques em 1898, deveu-se a disputas territoriais com a coroa britânica, aliado ao franco desenvolvimento da África do Sul, desencadeado pela descoberta de ouro (História de Moçambique, 2000).

Em resposta à discriminação étnica exercida por cidadãos do sul, nas regiões centro e norte de Moçambique, os moçambicanos nascidos a sul do rio Save são todos chamados por «machanganas», não se importando se o visado é Xironga, Cichopi, Bitonga ou Xitshwa, todos carregam a etnia Xichangana. É entendimento geral no centro-norte que a etnia que cultiva a discriminação de forma aberta e odiosa é a Xichangana, porém, na partilha de

\footnotetext{
${ }^{28}$ Formalizada através do Despacho do Ministro da Justiça, do dia 5 de Fevereiro de 1993, publicado no Boletim da República no 186, III Série, de 29 de Novembro de 2017.

${ }^{29}$ Significa coroa, em português.

${ }^{30}$ Civilização entendida no sentido de vida urbana, de cosmopolitismo e de acesso a meios de bem-estar.
} 
benefícios políticos e económicos todos os naturais a sul do rio Save são solidários, daí os restantes entenderem que são todos Xichanganas, porque todos são Tsongas, comungam e assumem a mesmas convicções étnicas, ainda que entre eles haja uma nítida separação dos perfis identitários e culturais.

\subsection{Deturpação da história, arma oculta da discriminação}

A História da FRELIMO está envolta de imprecisões e mistérios que colocam sérias dúvidas quanto ao rigor observado sobre os factos oficialmente anunciados. Há um coro cada vez crescente de vozes académicas que exige revisão da História de Moçambique, para clarificar muitos aspectos distorcidos, omitidos ou simplesmente suprimidos. Há quem afirme que tal ocorreu de forma propositada, para dar cobertura à ideologia política da FRELIMO, que enaltece virtudes de um nacionalismo selectivo, em benefício de determinados grupos étnicos, omitindo, nessa conveniência política, virtudes e bravura patrióticas de outros.

ADELINO TIMÓTEO (2017, p. 67) citando Aníbal Aleluia escreve que "o berço da resistência anti-portuguesa não é Gaza, como se convencionou por razões que me parecem tribais, mas Angoche, onde desde os tempos de Mogossurima, no século XVII, até ao sultanato de Farley, já no limiar deste século, os sultões cotis, de origem quiloana, opuseramse à cruz." JOSÉ CAPELA (2010, pp. 13-14) escreve que "não será portanto pela ignorância das diferenças que melhor se constituirá a nacionalidade moçambicana", referindo-se que sendo esse o projecto dos moçambicanos, se a historiografia tem aí um papel imprescindível a desempenhar, será a consciência apurada de tal realidade que mais e melhor poderá contribuir para os objectivos a atingir. Num outro desenvolvimento JOSÉ CAPELA especifica que "dir-se-á que esta é, afinal de contas, a posição de quem põe a historiografia ao serviço da política. O que inevitavelmente resvalaria para a ideologização da mesma historiografia".

Nessa perspectiva autores defendem que a criação da FRELIMO traz dados menos rigorosos e assume tendências bastante variadas. Por exemplo, ainda que se reconheça o prestígio de Eduardo Mondlane, não foi ele quem criou a FRELIMO, porque esta versão é refutada por muita gente da FRELIMO, principalmente pelos antigos integrantes da UDENAMO. Presume-se que para efeitos de glória e porque «a história é escrita pelos vencedores», a FRELIMO procurou «modificar e branquear» os factos, não só neste como noutros subsequentes, que foram surgindo em cada fase da luta, desenhando da maneira que pareceu aos protagonistas mais conveniente, ainda que para isso fosse adulterada a verdade. ${ }^{31}$

\footnotetext{
${ }^{31}$ Outros exemplos da distorção da história: consta da História de Moçambique que Eduardo Mondlane morreu no escritório da FRELIMO, quando na verdade morreu em Oyster Bay, em casa de Betty King; a FRELIMO sempre disse que a Luta Armada de Libertação Nacional iniciou exactamente em Chai, província de Cabo Delgado, mas general Bonifácio Gruveta, refuta essa versão, dizendo que foram vários locais superiormente identificados para o início da luta, na noite de 25 de Setembro de 1964, pelo que os primeiros combates foram vários, etc.
} 
A ocupação de Moçambique seja por ngunis ou portugueses nunca foi aceite com naturalidade, verificaram-se violentas batalhas entre os invasores e as populações locais de todo o território, de norte a sul, ainda que se acentue mais a resistência do sul em relação ao resto do país. Na verdade não houve povo algum ou etnia alguma que ficou receptivo, inerte ou passivo, mesmo na «Terra de Boa Gente», designação atribuída a Inhambane, em 1498, pelo navegador português, Vasco da Gama, a receptividade foi passageira. Vejamos:

a) Região Sul: a Batalha de Marracuene, também conhecida por Gwaza Muthini, evoca a resistência anti-colonial que opôs os guerreiros comandados por Nwamatibyana, Zihlahla, Mahazule, Mulungu e Mavzaya ao exército colonial português, comandado por Alfredo Augusto Caldas Xavier, numa expedição composta por 37 oficiais e 800 soldados. O confronto deu-se na madrugada de 2 de Fevereiro de 1895, com as forças invasoras dispostas em quadrado, uma táctica de guerra que foi usada pela primeira vez. ${ }^{32}$ Os nativos foram vencidos, em parte devido a vários factores tais como, superioridade bélica dos portugueses, traição dos Mavota e Matsolo, que cederam aos portugueses para que estes usassem as suas regiões como posto avançado das suas forças e, na fase decisiva, os Mavota que guiaram as forças portuguesas rumo ao combate de Marracuene, tudo isso aliado a questões como indisciplina no seio dos guerreiros de Nwamatibyana e seus súbditos, para além das divisões no seio das chefaturas de então, que foram optimizadas pelos portugueses. ${ }^{33}$ Nos meios oficiais esta traição é suavizada e ignorada, ainda que, em bom rigor, Gwaza Muthine celebre a heroicidade portuguesa, razão pela qual Portugal já exige a sua participação nas cerimónias anuais, uma pretensão que esconde no tapete diplomático uma manifestação de glória, pela histórica vitória;

b) Região Centro: a Revolta Báruè (1917-1918), resultante da desagregação do Estado de Muenemutapa, reino bastante poderoso, que conseguiu resistir à devastação Nguni e às disputas com os Estados Militares vizinhos, apesar de constantes e sucessivas crises de sucessão. O Estado Báruè gabava-se de invencível, por ter-se desembaraçado de dois temíveis homens de guerra da coroa portuguesa, quais sejam, João de Azevedo Coutinho, em 19 de Novembro de 1891 e Manuel António de Sousa, a 20 de Janeiro de $1892 .{ }^{34}$ Foram causas imediatas da revolta o facto de os portugueses terem decidido construir uma estrada ligando Tete e Macequece, passando pelas terras do Estado Báruè, para permitir aos invasores europeus o maior controlo administrativo das zonas do interior, para além do recrutamento massivo e

\footnotetext{
32 Fonte: <https://www.magazineindependente.com/cinco-mil-pessoas-esperadas-nas-celebracoes-dos-123-anos-do-gwazamuthine/>. Acesso em 13 de Junho de 2020.

33 Fonte: <https://noticias.sapo.mz/sociedade/artigos/gwaza-muthini-celebra-117o-aniversario-da-batalha-de-marracuene $>$. Acesso em 28 de Julho de 2019.

${ }^{34}$ Para mais informações, vide, em: <http://diquissine.blogspot.com/2015/05/revolta-de-barue.html>. Acesso em 12/06/2020. 
abusivo de homens para lutar contra alemães, na I Guerra Mundial (1914-1918). Na altura os alemães já haviam penetrado em território moçambicano, vindos do Tanganyika. O recrutamento dos homens era feito de forma muito brutal, com a ausência de salário, trabalho extremamente forçado e violação de mulheres pelos sipaios $^{35}$ e alguns europeus (História de Moçambique, 2000). Esta bravura nunca foi enaltecida pelas entidades oficiais, como orgulho da resistência moçambicana, consta, apenas, nos manuais da história;

c) Região Norte: nesta região como nas demais de 1895 até 1940 foram travadas violentas e sucessivas batalhas. Os principais chefes que se destinguiram foram MocutuMunu e Ibrahim (Monapo e Ilha de Moçambique). Outros chefes destacados são: Farlahi, de Angoxe, Mataca, de Niassa, e Mussa-Quanto, de Nampula. Farlahi e outros chefes de Monapo e da llha de Moçambique alcançaram sucessivas vitórias em bataIhas sangrentas. A principal batalha foi no quartel de Parapato em 1905 e distruição de vários quartéis portugueses até Mogincual (História de Moçambique, 2000). Pela síntese exigida para este trabalho destacamos a «Vitória dos Namarrais» nas batalhas travadas na região de Mugenga, em Mossuril, entre os nativos comandados por Mukuthu Muno, e as forças invasoras portuguesas, dirigidas por Mouzinho de Albuquerque, nos dias 19 e 20 de Outubro de 1896. Como consequência, a batalha foi ganha pelos nativos, com o temível Mouzinho de Albuquerque ferido, seu cavalo abatido e a respectiva carne consumida pelos nativos. Ao contrário das vitoriosas campanhas de Gaza, Mouzinho de Albuquerque fracassou contra os Namarrais em Nampula. O terreno, o inimigo, as tácticas e os equipamentos utilizados nada tinham a ver com o que sucedera em Gaza. Mouzinho de Albuquerque ao regressar a Lisboa foi recebido com frieza, morreu sem glória, numa rua em Benfica, com dois tiros na cabeça. $^{36}$

De entre as três zonas acima referidas, a que oficialmente teve privilégio de ser consagrada no protocolo do Estado para comemoração anual é a Batalha de Marracuene ou Gwaza Muthini, não havendo registo de decisão governamental igual para as outras regiões. Em Nampula, por iniciativa de um dirigente local, a Vitória dos Namarrais começou a ser comemorada recentemente. Assim, resulta claro que quando se enaltece Gwaza Muthini onde os moçambicanos foram vencidos, na região sul, parece haver um propósito, qual seja, o de transformar as derrotas sofridas no passado em vitórias e heroísmo, de modo que se ignore ou enfraqueça na percepção colectiva, a bravura e feitos heróicos das outras regiões, precisamente para manter o mito de que o berço da resistência frente aos portugueses foi no

\footnotetext{
35 Polícia indígena de Moçambique.

${ }^{36}$ Fonte: <https://delagoabayworld.wordpress.com/2012/04/19/mouzinho-e-a-campanha-dos-namarrais-1907/>. Acesso em 12 de Junho de 2020. Para mais informações, vide, ainda em: <https://jornalnoticias.co.mz/index.php/politica/60940-sobre-oexercito-portugues-vitoria-dos-namarrais-foi-ha-120-anos.html>. Acesso em 12 de Junho de 2020.
} 
Sul, especificamente em Gaza, omitindo a resistência contra ngunis. Autores como Aníbal Aleluia especificam que essa omissão é propositadamente estratégica, enquadra-se na actual postura estatal manifestamente discriminatória, que procura valorizar o heroísmo do Sul e minimizar ou abafar o patriotismo do resto do país, com batalhas historicamente memoráveis (ADELINO TIMÓTEO, 2019).

\subsection{Discriminação étnica associada a uma agressão externa}

Desde Outubro de 2017 que uma guerra não declarada devasta a Província de Cabo Delgado. Trata-se de uma guerra que pouco a pouco está a transformar-se num levantamento popular, como repúdio à exclusão social e a discriminação étnica. A zona de Palma e Mocímboa da Praia é da etnia Mwani, um grupo que tal como os Makuwas nunca foi levado em consideração pelo poder político, quando comparado com da etnia Shimakonde, uma etnia minoritária que vive nos distritos vizinhos de Muidumbe, Mueda e Nangade. ${ }^{37}$

Sobre a origem, causas e motivações do conflito, pronunciaram-se muitas figuras públicas, como o representante do Escritório das Nações Unidas para a Droga e Crime Organizado (UNODC) em Moçambique, César Guedes ${ }^{38}$, na entrevista que concedeu à LUSA $^{39}$ e Jacinto Veloso, antigo Ministro da Segurança de Moçambique. ${ }^{40}$ Muitos estudos também foram feitos, destacando-se o livro de Nuno Rogério, «Cabo do Medo. O Daesh em Moçambique (2019-2020)» ${ }^{41}$, o estudo do Instituto Tony Blair, «O conflito em Moçambique e a deterioração da situação de segurança» ${ }^{42}$, o estudo dos "Amigos da Terra», (Organização Não-Governamental Moçambicana), "Gás em Moçambique: uma bênção para a indústria, uma maldição para o país» ${ }^{43}$, o estudo do África Monitor, «Conflito 2017-2020 »"4 entre outros.

De forma clara e objectiva o estudo associa a insurgência com as razões históricas da discriminação étnica e exclusão social nos recentes desenvolvimentos da Província de Cabo Delgado foi feito pelo Instituto Chr Michelsen, «Guerra de recursos: o rico norte de Moçambique: cinco cenários».45 Outro estudo, mais claro ainda, foi feito pelo "Observatório

\footnotetext{
${ }^{37}$ Dados do Instituto Nacional de Estatística indicam que em Cabo Delgado o grupo maioritário são os Makuwas, seguido de Mwanis e por fim Shimakonde.

${ }^{38}$ César Guedes abriu o escritório de Moçambique há um ano, após um pedido do Governo à ONU, chegando a Maputo após dirigir a UNODC na Bolívia e depois de cinco anos no Paquistão - precisamente o país onde se fazem ao mar os barcos que atravessam o Oceano Índico com heroína até Moçambique.

${ }^{39}$ Fonte: <https://noticias.sapo.mz/actualidade/artigos/mocambiqueataques-trafico-de-droga-motiva-conflito-em-cabo-delgado> . Acesso em 7 de Junho de 2020.

${ }^{40}$ VELOSO, Jacinto (2020). A situação de Cabo Delgado - O cenário mais provável. Semanário SAVANA no 1378, de 5 de Junho de 2020, p. 4

${ }^{41}$ Fonte: $<$ https://pontosi.pt/opiniao/o-cabo-do-medo-um-livro-de-nuno-rogeiro/>. Acesso em 03/Julho/2020.

$42 \quad$ Fonte: $\quad<$ https://www.rtp.pt/noticias/mundo/instituto-tony-blair-sugere-intervencao-militar-regional-emmocambique n1238254>. Acesso em 3 de Julho de 2020.

Fonte: <https://estrategizando.pt/2020/06/17/amigos-da-terra-de-mocambique-denuncia-interesses-do-estado-e-deempresas-francesas-na-exploracao-de-gas-no-norte-de-mocambique-e-fala-numa-bomba-climatica/>. Acesso em 03/07/2020.

${ }^{44}$ Fonte: <https://www.africamonitor.net/pt/politica/africareport-moc2020522/>. Acesso em 3 de Julho de 2020.

45 Fonte: <https://www.cmi.no/publications/7233-guerra-no-norte-de-mocambique-uma-regiao-rica-em-recursos-naturais-seiscenarios $>$. Acesso em 3 de Julho de 2020.
} 
do Meio Rural» ${ }^{46}$ que faz uma abordagem minuciosa de factos históricos e aponta a marginalização dos povos das etnias Mwani e Makuwa, em relação às etnias Shimakonde e Xichangana, tidas como as mais privilegiadas. O estudo indica que em Dezembro de 2012, foi emitido um Direito de Uso e Aproveitamento da Terra (DUAT) provisório ao projecto da fábrica de liquefacção de gás natural em Palma de 7.000 hectares, implicando 0 reassentamento de 663 agregados familiares. "A aquisição de terrenos por parte de inúmeros indivíduos oriundos de fora do distrito (vulgo do Sul) é geradora de um sentimento de insegurança, de vulnerabilidade e de injustiça social' - refere o estudo.

O «Observatório do Meio Rural» avança que contrariamente à marginalização dos Mwanis elementos da etnia Shimakonde adquiriram protagonismo socioeconómico "beneficiando de empregos no Estado, de subsídios de antigos combatentes, ocupando as residências nos bairros militares nas capitais provinciais" e político "assumindo presença em cargos de decisão militar e da segurança ou funções de ideologização de populações urbanas". ${ }^{47} \mathrm{O}$ estudo coloca, de forma objectiva e clara, que a discriminação étnica e a exclusão social constituem as causas profundas do conflito.

\subsection{Discriminação étnica nos Projectos de Desenvolvimento}

Em Moçambique é frequente algumas Embaixadas, Organizações Internacionais e Não Governamentais esboçarem projectos de desenvolvimento para serem executados nas zonas rurais, sendo por isso encarados pelas populações locais como alternativa para criação de postos de trabalho, ainda que temporários. As práticas discriminatórias em projectos são matéria de análise de alguns autores que questionam sobre a modalidade que se usa no lançamento de vários projectos desenhados em Maputo, para cobrir as regiões centro e norte. De um modo geral sustenta-se que o corpo directivo, os técnicos e o pessoal de apoio para esses projectos é recrutado na região sul, ignorando-se a mão-de-obra da região onde será inserido o projecto, o que deixa indignada a população local. Além dos projectos temporários há outros de grande expressão económica, como Projectos de Areias Pesadas que ocupam o sexto lugar dos principais produtos de exportação de Moçambique ${ }^{48}$, localizados em Moma (Nampula), Inhassunge (Zambézia) Inharrime e Jangamo (Inhambane) e Chibuto (Gaza), onde também são apontados focos de discriminação.

A mineradora «Montepuez Ruby Mining, Limitada (MRM)», uma empresa que opera em Montepuez, (norte de Moçambique) constituída sob forma de sociedade por quotas de responsabilidade limitada, entre a «Gemfields Mauritius, Lda», com 75\% e a «Mwiriti,

\footnotetext{
${ }^{46}$ Mais informações, vide, em: <https://omrmz.org/omrweb/>. Acesso em 4 de Setembro de 2019.

47 Fonte: <https://noticias.sapo.cv/actualidade/artigos/mocambique-estudo-aponta-pobreza-como-causa-de-ataques-armadosem-cabo-delgado-norte-do-pais >. Acesso em 4 de Setembro de 2019.

48 Fonte: <https://noticias.sapo.mz/economia/artigos/mocambique-atribui-concessoes-de-areias-pesadas-de-escala-mundialmineradoras >. Acesso em 14 de Setembro de 2020.
} 
Limitada ${ }^{49}$ com 25\%, representada por Raimundo Pachinuapa (histórico da FRELIMO, da etnia Shimakonde) e Samora Machel Júnior (filho do primeiro presidente de Moçambique, da etnia Xichangana), constituem exemplo claro de que o etnicismo que floresce em Moçambique pode conduzir o país a uma situação de genocídio, tal como ocorreu em 1994 no Burundi e Ruanda, em que por apenas 100 dias cerca de 800 mil pessoas foram massacradas por extremistas étnicos Hútus e Tutsis, assim como seus adversários políticos, independentemente da sua origem étnica. ${ }^{50} \mathrm{~A}$ empresa MRM tem anunciado, pelo menos duas vezes por ano, receitas atractivas da venda de rubis ${ }^{51}$, realizadas fora do País ${ }^{52}$, em leilões que rondam em média os 37,2 milhões de dólares. ${ }^{53}$

Sucede, porém, que em Montepuez ${ }^{54}$ é do conhecimento público que quem descobriu em Namanhumbir, anos atrás, uma das áreas contendo elevadas quantidades de rubis de padrão internacional é o cidadão Selemane Assane, da etnia Makuwa. Alega-se que as populações locais esperavam que com a instalação da Montepuez Ruby Mining o cidadão que fez a descoberta fosse devidamente acarinhado, beneficiando-se de um conjunto de condições condignas, ou então fosse convertido em sócio da empresa, com uma percentagem ainda que mínima mas digna nos respectivos dividendos.

Contra todas as expectativas e possivelmente pelo seu baixo nível de escolaridade, refere-se que em 2015 Selemane Assane foi simplesmente contratado para operário, pela empresa Mwiriti e sujeitou-se de uma série de formações, como a continuação de estudos do Sistema Nacional de Educação, curso de informática na óptica do utilizador e formação em Gemologia nas Maurícias. Para além dessas formações, referem as fontes, a empresa construiu uma casa para Selemane Assane, casa essa que as populações consideram humilhante, fazendo fé às entrevistas realizadas pelo Centro de Jornalismo Investigativo (CJI). ${ }^{55}$ Nos fins de 2019 Selemane Assane terá cessado funções na empresa, acusado de vários crimes, como o desvio de dois cheques, falsificação de assinaturas e desvio de cerca de 50 mil Meticais. Alega-se ainda que Selemane foi capturado dentro da concessão da Montepuez Ruby Mining a realizar mineração ilegal, o que o levou à detenção e abertura do Processo-Crime no 321/CD/PRM-Montepuez, sob o qual está sendo exigido que ele pague uma multa no valor de 44.288,00 Meticais. ${ }^{56}$ Acusado de tantos crimes acredita-se que se Selemane Assane fosse da etnia Xichangana ou Shimakonde a sorte dele seria diferente.

\footnotetext{
${ }^{49}$ Boletim da República № 38, III Série, de 23 de Setembro de 2011.

50 Para mais dados:<https://www.bbc.com/portuguese/noticias/2014/04/140407 ruanda genocidio ms >. Acesso em 12 de Junho de 2020.

51 Por vezes o rubi é acompanhado de corindo - um mineral com base em óxido de alumínio em forma cristalina.

52 Para mais informação, vide, em: <https://cjimoz.org/news/as-sagas-de-selemane-assane-o-fundador-da-ruby-mining/> Acesso em 25 de Abril de 2020)

53 Fonte: <https://cipmoz.org/wp-content/uploads/2018/08/Montepuez-Ruby-Mining.pdf>. Acesso em 27 de Março de 2020.

${ }^{54} \mathrm{O}$ distrito de Montepuez localiza-se na província de Cabo Delgado, com a sede numa pequena cidade com o mesmo nome.

55 CJI, artigo sob o título «A(s) saga(s) de Selemane Assane o "fundador" da "Ruby Mining"». Informação disponível em: $<$ https://cjimoz.org/news/as-sagas-de-selemane-assane-o-fundador-da-ruby-mining/>. Acesso em 25 de Abril de 2020.

${ }^{56}$ Fonte: <https://cjimoz.org/news/as-sagas-de-selemane-assane-o-fundador-da-ruby-mining/>. Acesso em 25 de Abril de 2020.
} 
Em Montepuez não é só contra Selemane que a empresa exerceu violência. Em Abril de 2018, a firma de advogados defensores dos Direitos Humanos, a Leigh Day, intentou uma acção judicial junto do Supremo Tribunal de Londres, contra a Montepuez Ruby Mining (MRN), arrolando um conjunto de 273 queixas (incluindo 18 pessoas mortas pela segurança privada da MRN, pela polícia moçambicana que abateu algumas pessoas a tiro e outras espancadas até à morte ou queimadas vivas), e mais 200 queixas de espancamentos, tortura e abusos sexuais, em alguns casos com graves consequências, já que há lesões de incapacidade permanente, que impossibilitam ou limitam a normal mobilidade das vítimas para se fazerem ao trabalho e outras actividades. A Leigh Day sintetizou no processo judicial em "sérios abusos dos direitos humanos em torno da mina de Montepuez Ruby Mining (MRN)", pertencente ao grupo Gemfields ${ }^{57}$, com sede em Londres, entre 2011 e 2018, na aldeia de Namucho-Ntoro, Namanhumbir, em Montepuez. ${ }^{58}$

Da acção movida em tribunal resultou num acordo extra-judicial, em que a mineira Gemfields aceita pagar uma indemnização de 5,8 milhões de Libras (Correspondente a 8,3 milhões de Dólares; 7,25 milhões de Euros), para serem repartidos na seguinte ordem: (i) 4 milhões para reparação de estragos; (ii) 500 mil para a criação de um programa de reinstalação na aldeia Namucho-Ntoro, que foi avaliado como carecendo de reconstrução para alojar 100 famílias; e (iii) 1,8 milhões em honorários e custas da firma de Advogados. A mineradora aceitou, ainda, criar um painel que determinará a atribuição de compensações financeiras por queixas ou reclamações que venham a ser feitas no futuro, já que as investigações continuam. ${ }^{59}$ Os rostos visíveis da empresa encarnam as figuras de Raimundo Pachinuapa (Shimakonde) e Samora Machel Júnior (Xichangana) que são interpretados como os mentores morais da repressão dos makuwas que incorreram na violação dos Direitos Humanos, no que é interpretado como manifestações de complexo de superioridade e pelo desprezo que nutrem à etnia Makuwa, considerada inferior.

\subsection{Surgimento da RENAMO e os Acordos de Paz ineficazes}

Moçambique está em guerras sucessivas desde a década de 60 do século XX e, até aos dias que correm, nunca desfrutou de paz efectiva. A guerra é um fenómeno que afasta a paz na sociedade, provoca rupturas e, geralmente, força o estabelecimento de novos padrões de convivência. De entre os vários autores que se debruçam sobre a guerra, geralmente

\footnotetext{
57 ESTÁCIO VALOI, no seu artigo "Os rubis de sangue de Montepuez», de 2 de Junho de 2016. (Disponível em: $<$ https://landportal.org/pt/news/2016/07/os-rubis-de-sangue-de-montepuez>. Acesso em 25 de Abril de 2020).

58 LUSA, 29 de Janeiro de 2019. Disponível em: <https://www.dn.pt/lusa/gemfields-aceita-pagar-725-milhoes-em-indemnizacoespor-abusos-dos-direitos-humanos-em-mocambique-10502932.html>. Acesso em 8 de Abril de 2020.

59 Londres, "Notícias em Português", 9 de Abril de 2020, citando o «Newsletter Mozambique News Reports \& Clippings» Disponível em: <http://www.noticiasemportugues.co.uk/texto-diario/mostrar/1315024/gemfields-com-sede-em-londres-paga-58milhes-em-indenizaco-mortes-e-tortura-em-mocambique >. Acesso em 9 de Abril de 2020.
} 
afirmando que ela consiste na submissão da vontade, na imposição de pretensões por meio da força (Clausewitz, Marselle e Boutroux), Quincy Wright sustenta que "pode considerar-se a guerra como um conflito simultâneo de forças armadas, de sentimentos populares, de dogmas jurídicos, de culturas nacionais" (GASTON BOUTHOUL, 1966, pp. 42-53).

O Movimento Nacional de Resistência (MNR), posteriormente designado por Resistência Nacional Moçambicana (RENAMO), com a sua base na região centro e muita influência no norte, desencadeou uma guerra contra o Governo de Moçambique (1976-1992), invocando como causas a imposição de um governo socialista da ideologia MarxistaLeninista, implantação do sistema monopartidário, de campos de reeducação ${ }^{60}$, pena de morte por fuzilamento ${ }^{61}$ sem julgamento justo, aldeias e machambas comunais forçadas, ausência de eleições gerais periódicas, liberdade de circulação, de culto e religião, abolição da autoridade tradicional, entre outros. ${ }^{62}$ Porém, a base de todo o conflito é a discriminação étnica, ou seja, o crescente desprezo que a região do sul tem pelas regiões centro-norte.

Resultante do desprezo à RENAMO, esta não fez parte das conversações que levaram à assinatura do Acordo de Não-Agressão e Boa Vizinhança, mais conhecido por «Acordo de Nkomáti» ${ }^{63}$, no dia 16 de Março de 1984, entre Moçambique e África do Sul (RSA). Vários autores sustentam que o Governo de Moçambique acreditava que para acabar com a guerra bastava negociar com o financiador da mesma, a África do Sul, assumindo que a RENAMO era irrelevante, porque não passava de «bandidos armados». Como consequência, o acordo não surtiu o efeito desejado, beneficiou mais a RAS que ganhou visibilidade internacional, já que na época sofria um isolamento total, devido ao seu sistema de Apartheid.

O troar de armas cessou com o Acordo Geral de Paz (AGP) ${ }^{64}$, assinado em Roma, a 4 de Outubro de 1992, entre o Governo e a RENAMO, cujos documentos foram incorporados na legislação interna de Moçambique, através da Lei ํo 13/92, de 14 de Outubro. ${ }^{65}$ O AGP nunca foi cumprido, porque um dos motivos-base da guerra - a discriminação étnica - nunca figurou na agenda das conversações, acabando por reduzi-lo a um simples Acordo de CessarFogo. Os pronunciamentos inflamados das partes, que afastavam a reconciliação e unidade nacionais, em réplicas de desprezo étnico traduzido em violência verbal, revelam ausência de

\footnotetext{
${ }^{60}$ Sobre Campos de Reeducação, vide, ADELINO TIMÓTEO (2019:153).

${ }^{61}$ Lei no 2/79, de 1 de Março, Lei dos Crimes contra a Segurança do Povo e do Estado Popular, publicada no Boletim da República ํㅡㄴ 25, I Série, de 1 de Março de 1979.

62 Documentos do III Congresso da FRELIMO (Directivas Económicas e Sociais, Programas e Estatutos), publicados pelo Departamento do Trabalho Ideológico da FRELIMO; Resolução sobre a Organização dos Grupos Dinamizadores e Bairros Comunais; Documentos aprovados na I Reunião sobre Cidades e Bairros Comunais; Resolução sobre Aldeias Comunais dos Documentos da II Conferência Nacional do Trabalho Ideológico, realizado na Beira, de 5 a 10 de Junho de 1978; Resolução sobre Ofensiva Política e Organizacional e o Trabalho das Assembleias do Povo.

63 Para mais informações sobre o Acordo de Boa Vizinhança e Não Agressão (Acordo de Nkomáti), vide, em: $<$ http://www.folhademaputo.co.mz/pt/noticias/nacional/samora-assinou-acordo-de-nkomati-com-apartheid-para-tirar-o-pais-dosufoco/>. Acesso em 12 de Junho de 2020.

${ }^{64}$ Para mais dados sobre o Acordo Geral de Paz, assinado em Roma, entre o Governo de Moçambique e a RENAMO, vide, em: $<$ https://noticias.sapo.mz/actualidade/artigos/mocambique-celebra-hoje-25-anos-do-acordo-geral-de-paz-a-espera-deentendimento-efectivo >. Acesso em 12 de Junho de 2020.

${ }^{65}$ Boletim da República n 42, I Série, Suplemento, de 14 de Outubro de 1992.
} 
paz. Teodato Hunguana, um dos negociadores do AGP afirma que "nós não conseguimos fazer a reconciliação após o acordo de Roma, durante a sua implementação, e depois, ao longo dos últimos 25 anos. Como não conseguimos, ficamos todos armados para as eventualidades"66, o que significa que as mentes continuaram armadas. Observadores atentos anotam que o AGP foi tão linear que nem discutiu a criação da Comissão de Verdade e Reconciliação Nacional, para se conhecerem os autores dos crimes de guerra e responsabilizar-Ihes. Com a falta de responsabilização criminal e perdão colectivo da sociedade, a guerra voltou a fustigar populações, criando luto e refugiados internos e externos, ainda que em zonas localizadas.

O Acordo de Cessação de Hostilidades Militares, foi assinado no dia 5 de Setembro de 2014, entre o Governo de Moçambique e a RENAMO, posteriormente convertido em Lei $n^{\circ}$ 29/2014, de 9 de Setembro. ${ }^{67}$ Este acordo também não alcançou os propósitos almejados e a Equipa Militar de Observação das Hostilidades Militares (EMOCHIM), também não funcionou e foi desmantelada sem operar. Alguns autores escrevem que o acordo foi mais para agradar elites políticas e vender a boa imagem de Moçambique junto da comunidade internacional na véspera das eleições, porque pouco tempo depois, no silêncio oficial, a violência foi extremada, em 4 direcções: (i) caçar e assassinar Afonso Dhlakama, líder da RENAMO, numa cópia infeliz ao triste fim de Jonas Savimbi, líder da UNITA em Angola; (ii) caçar e abater elementos influentes dos Partidos Políticos da Oposição, através dos chamados «Esquadrões de Morte»; (iii) guerra urbana em Moçambique, direccionada ao sequestro/rapto, cárcere privado e extorsão de altos valores monetários à classe social com capacidade financeira; (iv) identificar académicos e políticos com visão e abordagem contrárias às defendidas pelo regime, avançando-se para operações de sequestro, tortura ou morte, conforme a gravidade dos seus pronunciamentos. Vários analistas referem que todos estes actos ocorrem sustentados, em parte, no contexto da discriminação étnica.

O Acordo de Reconciliação Nacional e Paz Definitiva de Maputo, foi assinado no dia 6 de Agosto de 2019,68 entre o Governo de Moçambique e a RENAMO. O ponto central foi a revisão da Constituição da República, para abrir espaço legal da descentralização administrativa que a RENAMO exigia ao longo das conversações. A Lei $n \times 0$ 1/2018, de 12 de $J_{u n h 0^{69}}$, formalizou a revisão pontual da Constituição da República de Moçambique (2004). Acto seguinte, foram aprovadas as leis que constituem o Pacote da Descentralização ${ }^{70}$, na perspectiva dos Governadores Provinciais passarem a ser eleitos e não designados pela confiança do Presidente da República. Afirma-se que o pacote legislativo da descentralização foi aprovado nitidamente para impedir que os Governadores Provinciais eleitos pelos Partidos

\footnotetext{
${ }^{66}$ Semanário SAVANA no 1383, de 10 de Julho de 2020, pp. 14-15.

67 Boletim da República $n^{\circ} 72$, I Série, $4^{\circ}$ Suplemento, de 9 de Setembro de 2014

68 Para leitura do texto integral, vide em: <https://clubofmozambique.com/wp-content/uploads/2019/08/acordo-de-paz-ereconcilia\%C3\%A7\%C3\%A3o-nacional-2019.pdf>. Acesso em 25 de Outubro de 2019.

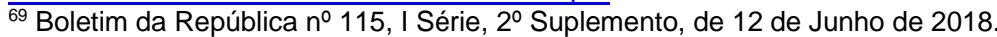

${ }^{70}$ Boletim da República no 105 , I Série, de 31 de Maio de 2019.
} 
da Oposição assumissem o poder efectivo, de tal forma que a figura de Secretário de Estado Provincial, designado pelo Presidente da República para gerir matérias não descentralizáveis, goza de amplos poderes do que o Governador Provincial eleito por sufrágio universal, directo e pessoal. TEODATO HUNGUANA é categórico em afirmar que "o facto político que deve prevalecer na Província é aquele que resulta do sufrágio universal". ${ }^{71}$ Alguns juristas são de entendimento de que se as leis são aprovadas para organizar e criar harmonia na sociedade, o pacote da descentralização criou uma generalizada indignação, o que faz supor que o Acordo de Reconciliação Nacional e Paz Definitiva de Maputo corre um sério risco de falhar como os anteriores acordos, em virtude da descentralização ter sido intencionalmente mal estruturada, para evitar que moçambicanos considerados de casta inferior assumissem o poder.

Há ainda uma decisão que divide opiniões tomada pela FRELIMO - Partido Governamental desde a Independência -, sempre governado por figuras do sul ${ }^{72}$, que optou por seleccionar figuras presidenciáveis por regiões, defendida como visando criar um pretenso equilíbrio étnico na governação do país, afastando-se do método universal da selecção de um bom servidor público com idoneidade, responsabilidade, conhecimentos e competência comprovados. A medida está produzindo efeitos contrários, porque foi legitimada aos olhos da sociedade a incompetência, a anarquia, o nepotismo e a discriminação étnica generalizada nos mais variados segmentos sociais e profissionais. A regionalização presidencial aumentou o clima de desconfiança entre governados e governantes e estimulou a exclusão, ou seja, acendeu os ânimos da conflitualidade, numa altura em que a sociedade clama por Paz. A formação do Governo obedece o mesmo cenário, não é aos profissionais e competentes que se chama ao executivo, mas sim aos bajuladores do regime, aos familiares ou confiados do Partido Político, o que fez instalar um clientelismo exclusivista. ${ }^{73}$ Para ser Deputado da Assembleia da República os Partidos Políticos fazem selecção não com base no conhecimento ou competência, mas sim no chamado «equilíbrio étnico», de tal modo que a maioria dos Deputados entra numa determinada legislatura e sai do Parlamento sem que se tenha pronunciado em qualquer sessão as matérias discutidas, limitando a votar às escuras, em assuntos que não entende.

\footnotetext{
${ }^{71}$ Semanário SAVANA no 1383 , de 10 de Julho de 2020, p. 2.

72 Eduardo Mondlane, primeiro Presidente da FRELIMO era de Gaza (região Sul); Samora Machel, primeiro Presidente de Moçambique independente, era de Gaza; após a sua morte foi substituído por Joaquim Chissano também de Gaza. Armando Guebuza que veio a seguir, ainda que tenha nascido em Murrupula (Nampula), região Norte onde o pai trabalhava, ele é de Maputo, o seu perfil cultural e manifestação de identidade não têm nenhuma conexão com os Makuwas, aliás ele é membro de Ngiyana, uma associação cívica da etnia Xironga. O actual Presidente Filipe Nyusi é da etnia Shimakonde, de Cabo Delgado (região Norte).

${ }_{73}$ Vide, a entrevista do Prof. Doutor Lourenço do Rosário, Chancelar da Universidade A Politécnica, publicada no Semanário SAVANA, no 1388 , de 14 de Agosto de 2020, pp. 2-3.
} 


\section{Conclusão}

Apesar do notável equilíbrio das disposições da Constituição da República de Moçambique, das diversas leis e documentos oficiais, a discriminação étnica é uma realidade na vida dos cidadãos em Moçambique, incluindo nas matérias sensíveis como a distribuição da riqueza nacional. A vida projecta-se em moldes diferenciados de acordo com a origem do cidadão, actos que se constatam dentro dos Partidos Políticos, nos estabelecimentos de ensino, nas unidades sanitárias, na valorização e promoção profissional e cultural e, com maior destaque, na ocupação dos postos de trabalho. Confirma-se, deste modo, a nossa hipótese segundo a qual «as elites políticas dominantes em Moçambique estimulam a discriminação étnica na sua acção governativa como forma de manutenção do poder, receiam que a sua hegemonia decisória nos destinos do país lhes escape e caia nas mãos de castas inferiores não confiáveis».

$\mathrm{Na}$ FRELIMO, por exemplo, para merecer confiança junto da actual nobreza (Xichangana e Shimakonde), o xingondo deve mostrar uma obediência acima da escala da indignidade, um verdadeiro espectáculo de vassalagem. Deve destacar-se na cultura da arrogância, do desprezo e cinismo frente aos outros xingondos, só para agradar as etnias dominantes e mostrar que ele é diferente, tal como o colono exigia ao negro assimilado em relação aos demais indígenas. Os exemplos são vários: Manuel Tomé, quando Chefe da Bancada da FRELIMO na Assembleia da República; José Pacheco, quando representante do Governo nas negociações com a RENAMO no Centro de Conferências Joaquim Chissano; Damião José, quando assumia as funções de Secretário do Comité Central da FRELIMO para a Mobilização e Propaganda, etc., exemplos claros em que pisando os semelhantes os autores ridicularizaram-se publicamente, no penoso exercício de busca de aceitação, mesmo reconhecendo que a igualdade daí obtida será manifestamente forçada e sob reserva, com movimentos devidamente vigiados, numa monitoria que visa descartá-lo, caso não sirva para os interesses estratégicos em vista.

A discriminação étnica agride a cidadania, viola o direito a igualdade de oportunidades, interfere negativamente nas políticas públicas, desqualifica cidadãos na sua personalidade jurídica, inviabiliza a mais correcta estruturação e distribuição da riqueza nacional, policia nomeações para cargos de prestígio e coisifica camadas sociais fomentando ódio. A discriminação étnica é a principal inimiga dos moçambicanos que deve ser colocada na mesa de todas as negociações de forma transversal, seja para que matéria for agendada. Os cordos de paz assinados em Moçambique nunca surtiram o efeito esperado porque a discriminação étnica, racial e religiosa, a exclusão social não têm merecido atenção especial para marcarem presença nas agendas negociais. Os valores da Unidade Nacional, fortalecem-se na base de respeito pela diferença, configurando um quadro de igualdade na diversidade. 


\section{REFERÊNCIAS}

ALVES, Tânia Pires. A minha Pátria é Moçambique - Testemunhos de Joaquim Chissano, Mia Couto, Afonso Dhlakama e outras personalidades políticas e artísticas, Lisboa: Guerra e Paz Editores, SA, 2017.

BOUTHOUL, Gaston. O fenómeno guerra, Colecção Ideias e Formas - 3 - Lisboa: Estúdios Cor [Trad. De António Simões Neto], 1966.

CAHEN, Michel. Moçambique: o "fim da história" ... única - Trajectória dos anticolonialismos em Moçambique, Porto: Africana Studia, no 15, Edição do Centro de Estudos Africanos da Universidade do Porto, pp. 195-240, 2010.

CAPELA, José. Moçambique pela sua história, Colecção: Estudos Africanos - 6, Famalicão: Húmus, 2010.

CHICHAVA, Sérgio. Por uma leitura Sócio Histórica da Etnicidade em Moçambique, Maputo: Instituto de Estudos Sociais e Económicos (IESE), 2008. Disponível em: $<$ http://www.iese.ac.mz/sergio-inacio-chichava/>. Acesso em 28 de Julho de 2019.

Estatuto do Funcionalismo Ultramarino, aprovado pelo Decreto-Lei oㅜ 46.982, de 27 de Abril de 1966, Lourenço Marques: Imprensa Nacional de Moçambique, 1966.

GONÇALVES, Jaime Pedro. A Paz dos Moçambicanos, Maputo: CIEDIMA, Lda, 2014.

HISTÓRIA DE MOÇAMBIQUE, [Dir. Carlos Serra], Parte I - Primeiras Sociedades Sedentárias e Impacto dos Mercadores, 200/300-1885; Parte II - Agressão Imperialista, 1886-1930, Volume 1, Maputo: Livraria Universitária, Universidade Eduardo Mondlane, 2000.

JARDIM, Jorge. Moçambique Terra Queimada, Lisboa: Editorial Intervenção, 1976.

LAWEKI, Lawe. Mateus Pinho Gwenjere - Um Padre Revolucionário, Lisboa: Vanessa Finaughty for Reach Publishers, 2019.

MARTELO, David. 1974 Cessar-Fogo em África, Mem Martins: Publicações EuropaAmérica, 2001.

NALYAMBIPANO, Salésio Teodoro. A minha contribuição para a Independência e Edificação do Estado Moçambicano: Memórias de um General da Linha da Frente, Maputo: Gabinete de Estudos da Presidência da República, 2013.

NCOMO, Barnabé Lucas. Uria Simango - Um homem, Uma causa, $3^{a}$ ed, Maputo: Edições Novafrica, 2003.

NGUNGA, Armindo; FAQUIR, Osvaldo Girrugo, «Padronização da ortografia de línguas mocambicanas: Relatório do III Seminário» (PDF). Maputo: Centro de Estudos Africanos (CEA), Universidade de Eduardo Mondlane. As nossas línguas (3), 2012.

SERRA, Carlos [Dir.]. Racismo, Etnicidade e Poder: Um estudo em cinco Cidades de Moçambique, Maputo: Livraria Universitária, Universidade Eduardo Mondlane, 2000.

TIMÓTEO, Adelino. Os últimos dias de Uria Simango, Maputo, 2017.

TIMÓTEO, Adelino. Afonso Dhlakama - A longa luta em defesa da Democracia, Tomo 1, Maputo, 2019. 